\title{
JUDICIAL ADMINISTRATION BEYOND THE ORANGE RIVER FROM 1839 TO 1843: THE FIRST MAGISTRATES AND THEIR DUTIES
}

\author{
Liezl Wildenboer*
}

\section{ABSTRACT}

In the aftermath of the Great Trek, the emigrant farmers settled in the areas that would later become known as Natal, the Zuid-Afrikaansche Republiek and the Orange Free State. From October 1840 until August 1843 these areas were administered as one territory and were governed by the Natal Volksraad seated at Pietermaritzburg. As early as 1839 the Natal Volksraad demarcated districts and appointed magistrates for each district. These districts were Pietermaritzburg, Port Natal, Weenen, Potchefstroom and Winburg. During this early period, the magistrates were tasked with duties beyond their usual judicial responsibilities. This contribution takes a closer look at the office of the magistrate beyond the Orange River during the period from 1839 to 1843 by looking first at the individuals who were appointed to these positions, and secondly by examining some of their duties as are evident from the minutes of the Natal Volksraad.

Keywords: Early administration of justice; Natal; Zuid-Afrikaansche Republiek; Orange Free State; magistrate; Pietermaritzburg; Port Natal; Weenen; Potchefstroom; Schoonspruit; Winburg; judicial duties; non-judicial duties; Orphan Chamber; harbour master

* Senior lecturer, Department of Jurisprudence, University of South Africa. 


\section{The magistrates' courts until 1843}

The administration of justice in South Africa beyond the Orange River during the period from 1838 to 1843 has been discussed elsewhere. ${ }^{1}$ That contribution looked at the administration of justice in Natal and in the territory west of the Drakensberg during the years after the arrival of the Voortrekkers until the adjunct council at Potchefstroom declared itself independent from Natal in August 1843 following the British annexation of Natal. ${ }^{2}$ Since no law reports for this period exist, not much is known about the administration of justice at the time. What little we do know is gleaned from surviving regulatory documents, minutes of the Volksraad and other related documents of that time. These documents give some indication of the basic judicial structures and the jurisdiction of the courts during that period.

Nevertheless, as any lawyer knows, the devil is in the details and the administration of justice entails specific processes and duties. It is therefore useful to take a closer look at the duties of the most important official responsible for the administration of justice at that time, the magistrate. This contribution therefore briefly discusses the office of the magistrate during those early years. First, the various magisterial districts established in Natal and the territory west of the Drakensberg are identified. This includes an inventory of the individuals that were appointed to these offices between 1838 and August 1843. Secondly, an attempt is then made to give an indication of the various duties of the magistrates as evidenced by their instructions received from and their correspondence with the Volksraad.

\section{The magistrates' courts and the first magistrates}

\section{Pietermaritzburg}

Pietermaritzburg was viewed as the capital of Natal. It was the main seat of government and most of the Volksraad meetings were held there. ${ }^{3}$

On 29 June 1839 PR Nel was provisionally appointed as the first magistrate for Pietermaritzburg. ${ }^{4}$ Six months later he was succeeded by JP Zietsman who was

1 Wildenboer 2016: 173-190.

2 The areas east and west of the Drakensberg were theoretically governed as one territory from 16 Oct 1840 until the Potchefstroom adjunct council's declaration of independence. For more on the adjunct council and the British annexation of Natal, see Wildenboer 2016: $174 \mathrm{nn} 1 \& 2$ and the sources cited there.

3 According to the contemporary account by Erasmus Smit, Pietermaritzburg was established on 23 Oct 1838 and was named after Piet Retief and Gerhard Maritz - see Preller 1988: 166, entry of Tues 23 Oct 1838 .

4 For the appointment of Nel, see Volksraadsnotule Natal: 12-14, art 12 of the minutes of the Volksraad of 29 Jun 1839. See, also, Preller 1920: 275-291: "Verhaal van Dirk Uijs", esp at 290 where it is noted that Philip Nel was the first magistrate of Maritzburg, and that he was succeeded by "Sietsema" (Zietsman); and Preller 1938: 111-182: "Herinneringe van JH Hattingh Sr" at 135. 
appointed for a period of one year. ${ }^{5}$ Zietsman swore an oath in his official capacity on 3 January $1840,{ }^{6}$ but applied for resignation five months later in May $1840^{7}$ after complaints of partiality were received. The complaints concerned the case of one Lingenfelder who had allegedly flouted the laws regarding liquor licences and had then not been prosecuted by Zietsman. ${ }^{8}$ In his defence, Zietsman pointed out that the matter fell outside his jurisdiction as the events had occurred during a military expedition ${ }^{9}$ and should therefore have been addressed by the military commander. It is assumed that the matter was settled amicably and unofficially as the matter was not raised again. In any event, Zietsman's resignation was not seriously considered and was never tabled at the Volksraad; he remained in his position as magistrate until January $1841^{10}$ and was officially thanked by the Volksraad for his work during his term as magistrate. ${ }^{11}$

In February $1841 \mathrm{JN}$ Boshoff ${ }^{12}$ - who would later be elected as president of the Orange Free State in 1855 - was appointed as magistrate of Pietermaritzburg. ${ }^{13}$ He took his oath as magistrate on 1 February $1841 .{ }^{14}$ Although he was originally appointed for a period of six months, his contract was later renewed..$^{15}$ He remained in this position until his resignation in August $1842^{16}$ and was also thanked for his term of service. ${ }^{17}$

JB Rudolph was appointed as magistrate from 1 November $1842,{ }^{18}$ but he did not remain in office for long. On 24 October 1842 - even before his term officially started

5 Volksraadsnotule Natal: 24-25, art 3 of the minutes of the Volksraad of Dec 1839 (specific date unknown).

6 Volksraadsnotule Natal: 26-28, art 1 of the minutes of the Volksraad of 3 Jan 1840.

7 For Zietsman's application for resignation, see his letter dated 9 May 1840 published in Volksraadsnotule Natal: 346, app 22/1840.

8 For a discussion of the allegations against Zietsman, see Volksraadsnotule Natal: 31-32, art 5 of the minutes of the Volksraad of 4 Mar 1840; and Volksraadsnotule Natal: 32-34, art 1 of the minutes of the Volksraad of 5 Mar 1840.

9 For an account of the events during the military expedition, see Volksraadsnotule Natal: 324-339, app 11/1840, esp at 331 and 335-336.

10 Zietsman was allowed to resign only in Nov 1840 but he was required to serve his full term until Jan 1841: see Volksraadsnotule Natal: 68-70, art 10 of the minutes of the Volksraad of 17 Nov 1840 .

11 Volksraadsnotule Natal: 81-85, art 1 of the minutes of the Volksraad of 2 Feb 1841.

12 For more on Boshoff, see Wildenboer 2016: $175 \mathrm{n} 6$.

13 Volksraadsnotule Natal: 76-77, art 6(a) of the minutes of the Volksraad of 19 Jan 1841. Boshoff would receive $£ 50$ remuneration and he was required to stay on for three months if he resigned.

14 Volksraadsnotule Natal: 80-81, art 2 of the minutes of the Volksraad of 1 Feb 1841.

15 In Aug 1841 his contract was renewed for an unspecified period of time - see Volksraadsnotule Natal: 109-110, art 9 of the minutes of the Volksraad of 4 Aug 1841.

16 Volksraadsnotule Natal: 157-159, art 11 of the minutes of the Volksraad of 8-10 Aug 1842. He was required to remain in office for another three months.

17 Volksraadsnotule Natal: 160-165, art 39 of the minutes of the Volksraad of 4-6 Oct 1842.

18 Ibid. 
- he called a special meeting of a commission of the Volksraad and gave notice that he had to undertake an urgent and long overdue trip to the interior. Unfortunately the existing evidence does not give the reasons for this trip. He requested that someone else be appointed to take over his duties in his absence. However, the commission was not sympathetic and instructed Rudolph to postpone his trip until January the next year when he could motivate his absence in front of the full sitting of the Volksraad. They also stipulated that, in the event that the trip became absolutely unavoidable, Rudolph had to give the Volksraad fourteen days' notice to enable them to appoint the eldest member of the heemraden in his absence. ${ }^{19}$ Rudolph probably could not postpone his trip further and eventually simply resigned in early January 1843, but had to remain in office for another three months. ${ }^{20}$

In April 1843 former magistrate Zietsman was re-appointed, this time for a term of one year. ${ }^{21} \mathrm{He}$ would receive $£ 100$ for his services, with the promise of further remuneration if government finances allowed.

\section{Port Natal}

There had been a British settlement at Congella as early as $1824 .{ }^{22}$ From June 1839 the Boers who reached Port Natal settled at three different locations near the rivers respectively known as the "Congela", the "Umgeni" and the "Omlaas". The name "Port Natal" was the name of the district ${ }^{23}$ encompassing the entire bay of Natal (today known as Durban) and the surrounding territory. "Congella" referred to the settlement within the district of Port Natal. The two names were, however, sometimes used interchangeably. ${ }^{24}$ In one early document the magistrate of Port Natal was also

19 Volksraadsnotule Natal: 165, art 1 of the minutes of the meeting of the commission of the Volksraad upon request of JB Rudolph on 24 Oct 1842.

20 Volksraadsnotule Natal: 167-170, art 2 of the minutes of the Volksraad of 2-4 Jan 1843. He was required to remain in office for three months.

21 Volksraadsnotule Natal: 173-177, art 1 of the minutes of the Volksraad of 3-6 Apr 1843.

22 For the early British settlement at Port Natal, see Theal 1908: 295ff. A small group of people under the leadership of FG Farewell settled at Port Natal on land granted to them by King Shaka. They had received a grant of "the port or harbour of Natal" from King Shaka when one member of the group had saved his life after a failed assassination attempt. For the document granting the land to "FG Farewell and Company", see Bird 1888: 191-195. Congella had been a settlement on the banks of the river to the north of the bay of Natal: see the copy of the 1824 hand-drawn map of Durban available at http://www.south-africa-tours-and-travel.com/history-of-durban. html (accessed 21 Apr 2015). However, there remains uncertainty about the first inhabitants of Congella (also known as Khangela or Kangela) - see Koopman 2004: 81-83.

23 For an explicit reference to "the district of Port Natal", see Volksraadsnotule Natal: 157-159, art 18 of the minutes of the Volksraad of 8-10 Aug 1842. See, also, Volksraadsnotule Natal: 144146, art 10 of the minutes of the Volksraad of $25 \mathrm{Feb} 1842$, in which petitions for plots of land in Congella were referred to the magistrate of Port Natal.

24 See, eg, Eybers 1918: 143, doc 91 which states that the treaty of 1835 between the British residents and Dingaan was "done at Congella" and "signed on behalf of the British Residents at Port Natal". 
referred to as the magistrate of Tugela. ${ }^{25}$ However, the territory that Dingaan had ceded to the Boers included only land south of the Tugela River and could therefore only have included the area south of that river. ${ }^{26}$ Today, the name "Congella" is probably better known for the battle that took place there in May 1842 between the Boer forces and British soldiers under the command of Captain TC Smith. Smith's forces were besieged and were saved by a relief force sent from Cape Town after Dick King's famous 500 miles journey on horseback to Grahamstown in ten days. ${ }^{27}$

One of the British inhabitants, Alexander Biggar, was appointed as the first magistrate of Port Natal in May $1838 .{ }^{28}$ Biggar resigned a few weeks later due to personal circumstances. It has been suggested that he suffered from depression following the death of both his sons and that this led to his resignation. ${ }^{29}$ Biggar himself died in battle shortly after on 27 December $1838 .{ }^{30}$

FJ de Jager was provisionally appointed in June $1839 .{ }^{31}$ However, he apparently requested assistance, because barely a month later PJ Joubert was provisionally appointed as magistrate along with four heemraden, De Jager being one of them. ${ }^{32} \mathrm{It}$ is not certain for how long Joubert remained in office as the date of the appointment of his successor is unclear.

Although there is no official record of his appointment as magistrate, F Roos had already resigned from this position by April $1840 .{ }^{33} \mathrm{He}$ officiated as magistrate as early as September $1839^{34}$ and in October 1839 he headed the embassy to Mpande

25 See the extract from the report of the magistrate of Tugela on his embassy to Mpande (Panda) in Oct 1839 as it appeared in De Zuid Afrikaan of 29 Nov 1839; also published in Volksraadsnotule Natal: 309-312, app 28/1839. The purpose of the embassy to Mpande was to officially recognise him as the Zulu leader and as Dingaan's successor. The Volksraad undertook to support Mpande against Dingaan and in return Mpande would settle Dingaan's debt to the Volksraad. For more on the embassy to Panda, see Nathan 1937: 284-285; Theal 1915: 392; Stockenström 1925: 18-19.

26 See Eybers 1918: 148-149, doc 95.

27 See Theal 1908: 369-374; Davenport \& Saunders 2000: 113; Stockenström 1925: 38-47. See, also, Cubbin 1992: 48-69 for a discussion of the events that led to the confrontation at Congella. For more on King, see Tabler 1977: 64-66.

28 Volksraadsnotule Natal: 407, app 4/1842, esp the postscript to attachment IV. See Theal 1915: 377 and Nathan 1937: 239 who claim that Biggar was succeeded by L Badenhorst. However, I could not find any official evidence of Badenhorst's appointment as magistrate before Sep 1840 (see $\mathrm{n}$ 45 infra). For more on Biggar, see Tabler 1977: 12-13.

29 Nathan 1937: 239; Theal 1915: 377.

30 Nathan 1937: 265.

31 Volksraadsnotule Natal: 12, art 8 of the minutes of the Volksraad of 28 Jun 1839.

32 See art 4 of the minutes of the Volksraad of 29 Jul 1839 published in Eybers 1918: 152-153, doc 99.

33 Volksraadsnotule Natal: 38-42, art 1 of the minutes of the Volksraad of 4 Apr 1840.

34 Volksraadsnotule Natal: 15-16, art 11 of the minutes of the Volksraad of 6 Sep 1839; Volksraadsnotule Natal: 17-18, art 2 of the minutes of the Volksraad of 3 Oct 1839. 
as the "landdrost of Tugela" (magistrate of Tugela).$^{35}$ On 4 April 1840 P Ferreira was appointed as Roos' successor in an acting capacity, ${ }^{36}$ although it is uncertain who performed the official duties during the next few months. Documentary evidence suggests that Roos, despite his resignation, remained in his position ${ }^{37}$ until he again tendered his written resignation in August $1840^{38}$ after complaints that he had left his position. ${ }^{39}$ Despite receiving a plot of land as reward for his services, financial difficulties may have contributed to his resignation as he was required to pay his travel expenses incurred in his official capacity from his monthly salary of fifty rijksdaalders..$^{40}$ This may explain why he successfully applied for permission to act as notary directly after his resignation. ${ }^{41}$

P Ferreira was immediately reappointed in an acting capacity, ${ }^{42}$ but he also resigned shortly thereafter in September $1840 .{ }^{43}$ Ferreira's request was initially declined due to a debacle about a missing boat and the subsequent confusion about the person responsible for granting permission for the use of the boat to two employees or servants of a certain Dr Bucken. ${ }^{44}$ Unfortunately it is unclear what the outcome of this debacle was as no further mention is made of it in the existing evidence.

In September 1840, L Badenhorst was elected by way of vote and subsequently appointed as magistrate for Port Natal. ${ }^{45}$ Nevertheless, it appears that the Volksraad anticipated problems regarding Badenhorst's availability for his official duties: when Badenhorst was appointed, it was determined even at that stage that Ferreira would still act as provisional magistrate during Badenhorst's absence. ${ }^{46}$ This measure seems to have been insufficient, because in January 1841 the Volksraad resolved that, in the district of Port Natal, the eldest member of the heemraden should act as magistrate

35 Nathan 1937: 284-285; Theal 1915: 392. See, also, n 25 supra. Stockenström 1925: 18-19 erroneously states that the embassy was headed by magistrate Servaas van Breda; however, Roos himself confirms in his report that Van Breda merely accompanied the embassy in his capacity as a member of the heemraden - see Volksraadsnotule Natal: 309-312, app 28/1839. Volksraadsnotule Natal: 38-42, art 1 of the minutes of the Volksraad of 4 Apr 1840.

37 Roos is on record as the magistrate for Port Natal as late as Jun 1840 - see Volksraadsnotule Natal: 44-46, arts 2-5 of the minutes of the Volksraad of 5 Jun 1840. One source mentions that Roos was still the magistrate of Port Natal as late as 9 Jul 1840 - see Preller 1938: 5-54: "'n Natalse dagboek van 1840", esp at 12.

38 Volksraadsnotule Natal: 52-53, art 2 of the minutes of the Volksraad of 8 Aug 1840.

39 Volksraadsnotule Natal: 48-49, art 2 of the minutes of the Volksraad of 5 Aug 1840.

40 Volksraadsnotule Natal: 44-46, art 4 of the minutes of the Volksraad of 5 Jun 1840; and Volksraadsnotule Natal: 56-57, art 5 of the minutes of the Volksraad of 12 Aug 1840.

41 Volksraadsnotule Natal: 52-53, art 4 of the minutes of the Volksraad of 8 Aug 1840, being the same day that his letter of resignation was accepted by the Volksraad.

42 Volksraadsnotule Natal: 52-53, art 3 of the minutes of the Volksraad of 8 Aug 1840.

43 Volksraadsnotule Natal: 62-65, art 21 of the minutes of the Volksraad of 29 Sep 1840.

44 Ibid.

45 Volksraadsnotule Natal: 60-62, art 11 of the minutes of the Volksraad of 4 Sep 1840.

46 Ibid. See, in general, Anonymous 1977: 40-41. 
for an annual salary of $£ 50$ until further notice. ${ }^{47}$ Not even this temporary measure could resolve the issue and in February 1841 AWJ Pretorius and CP Landman were officially appointed to find somebody for the position. ${ }^{48}$ As a result, the Volksraad finally appointed JS Maritz in April $1841^{49}$ and he took the oath on the same day. Maritz resigned after a year. ${ }^{50}$ His successor, J Bodenstein, was appointed in April 1842 in the dual capacity of magistrate and harbour master. ${ }^{51}$

In August 1842 the district of Port Natal was merged with the district of Pietermaritzburg. ${ }^{52}$ The reasons for this decision are unclear, but it is possible that the persistent problems regarding the availability of a magistrate for Port Natal may have contributed. Consequently, Bodenstein was requested to hand over all official books and paperwork to the magistrate of Pietermaritzburg and the office of the magistrate for Port Natal ceased to exist. ${ }^{53}$

\section{Weenen}

Weenen was established in August $1840 .{ }^{54}$ AT Spies was provisionally appointed as the first magistrate for a period of six months..$^{55}$ At the time of his appointment, Spies already officiated as commandant for Weenen. The Volksraad decision provided that he was allowed to occupy both positions, but that his judicial duties had preference; in the event that his judicial duties prevented him from performing his military duties, the eldest field-cornet had to take over such military duties. At the end of the six-month period, the Volksraad received a petition from forty local inhabitants requesting that Spies remain as magistrate. ${ }^{56}$ After making some enquiries, the Volksraad expressed its satisfaction with the work done by Spies and renewed his

47 Volksraadsnotule Natal: 77-79, art 1 of the supplementary minutes of the Volksraad of 14-19 Jan 1841.

48 Volksraadsnotule Natal: 81-85, art 22 of the minutes of the Volksraad of 2 Feb 1841.

49 Volksraadsnotule Natal: 92-94, arts 15 \& 16 of the minutes of the Volksraad of 12 Apr 1841. He was appointed for a period of one year at a salary of 1333:2:4 rijksdaalders.

50 Volksraadsnotule Natal: 132-135, art 12 of the minutes of the Volksraad of 8 Jan 1842. He gave three months' notice.

51 Volksraadsnotule Natal: 151-152, art 3 of the minutes of the Volksraad of 28 Apr 1842. During the transitional period before Bodenstein's appointment, M Stadelaar very generously offered his services free of charge; this offer was gratefully accepted - see Volksraadsnotule Natal: 144-146, art 5 of the minutes of the Volksraad of 25 Feb 1842.

52 Volksraadsnotule Natal: 157-159, art 18 of the minutes of the Volksraad of 8-10 Aug 1842. For a description of the former boundary between the two districts, see Volksraadsnotule Natal: 56-57, art 6 of the minutes of the Volksraad of 12 Aug 1840.

53 Volksraadsnotule Natal: 157-159, art 19 of the minutes of the Volksraad of 8-10 Aug 1842.

54 For a description of the boundaries of Weenen, see Volksraadsnotule Natal: 57-58, art 2 of the minutes of the Volksraad of 13 Aug 1840.

55 Volksraadsnotule Natal: 57-58, art 3 of the minutes of the Volksraad of 13 Aug 1840.

56 Volksraadsnotule Natal: 81-85, art 21 of the minutes of the Volksraad of 2 Feb 1841. 
contract. ${ }^{57}$ Spies resigned a year later ${ }^{58}$ but he was required to remain in office for a further three months. During the transitional period, and until a new magistrate was appointed, the eldest member of the heemraden was required to step in if requested to do so. ${ }^{59}$ At some point, FJ de Jager acted as magistrate for Weenen from March 1841, but he resigned a few weeks later in April 1841, citing his apparent inability to cope with the responsibilities of the position. ${ }^{60}$

W Jacobs was elected as magistrate and appointed in April $1842^{61}$ and took his oath on the twenty-ninth of that month. ${ }^{62}$ When he resigned at the beginning of $1843,{ }^{63}$ he was told that he could only resign after he had cleared his name of a complaint received against him. ${ }^{64}$ The matter was referred to the (acting) magistrate and heemraden but it is not certain what the outcome of the dispute was ${ }^{65}$ No further mention of the complaint against Jacobs is made in the official documentation and the nature of the complaint remains unknown. Nevertheless, there appears to have been irregularities in the accounts of both Jacobs and his predecessor, Spies. ${ }^{66}$

In April 1843, T Dannhauser was appointed as a member of the heemraden and, in addition, would act as magistrate in the interim. ${ }^{67}$ His accounts appear to have been in order. ${ }^{68}$ However, his authority was questioned by some of the local inhabitants and he eventually resigned in April 1845. ${ }^{69}$

\section{The territory west of the Drakensberg}

The territory west of the Drakensberg during this period consisted of two districts, namely that of Potchefstroom and Winburg. The district of Potchefstroom (also referred to in early documents as Mooirivier) was situated north of the Vaal River in the area that would later be known as the Zuid-Afrikaansche Republiek. The district

57 Ibid. In terms of his renewed contract he would receive remuneration of fifty rijksdaalders per month for work already performed, and seventy-five rijksdaalders per month thenceforth - see Volksraadsnotule Natal: 88-89, art 2 of the minutes of the Volksraad of 9 Apr 1841.

58 Volksraadsnotule Natal: 125-126, art 5 of the minutes of the Volksraad of 4 Jan 1842.

59 Volksraadsnotule Natal: 142-144, art 13 of the minutes of the Volksraad of 24 Feb 1842.

60 Volksraadsnotule Natal: 15 n 20; Volksraadsnotule Natal: 88, art 3 of the minutes of the Volksraad of 8 Apr 1841.

61 Volksraadsnotule Natal: 150-151, art 5 of the minutes of the Volksraad of 27 Apr 1842.

62 Volksraadsnotule Natal: 152-155, art 5 of the minutes of the Volksraad of 29 Apr 1842.

63 Volksraadsnotule Natal: 167-170, art 1 of the minutes of the Volksraad of 3 Jan 1843.

64 Volksraadsnotule Natal: 173-177, arts $7 \& 12$ of the minutes of the Volksraad of 3-6 Apr 1843.

65 Volksraadsnotule Natal: 178-180, art 8 of the minutes of the Volksraad of 4-5 Sep 1843.

66 Volksraadsnotule Natal: 173-177, art 36 of the minutes of the Volksraad of 3-6 Apr 1843; and Volksraadsnotule Natal: 186-188, art 4 of the minutes of the Volksraad of 3-4 Jun 1844.

67 Volksraadsnotule Natal: 173-177, art 12 of the minutes of the Volksraad of 3-6 Apr 1843.

68 Volksraadsnotule Natal: 198-201, art 19 of the minutes of the Volksraad of 7-8 Apr 1845.

69 Volksraadsnotule Natal: 195-197, art 6 of the minutes of the Volksraad of 6-7 Jan 1845; Volksraadsnotule Natal: 198-201, art 7 of the minutes of the Volksraad of 7-8 Apr 1845. 
of Winburg (also referred to as Santrivier, Sandrivier or Vetrivier) ${ }^{70}$ was situated north of the Orange River, but south of the Vaal River in the area that would later become known as the Orange Free State. ${ }^{71}$

\section{Potchefstroom}

In September 1839 the Natal Volksraad appointed J de Klerk ${ }^{72}$ as the first magistrate for the area "on the other side of the Drakensberg" (my translation) ${ }^{73}$ Initially, and for political reasons, the magistrate sat not at Potchefstroom, but at Schoonspruit (today known as Klerksdorp).$^{74}$ It has been suggested ${ }^{75}$ that the reasons for the choice of Schoonspruit as the first seat of the magistrate's court were twofold and politically motivated: First, the Natal Volksraad did not want to recognise Potchefstroom as a town as that would elevate the status of its leader, Andries Hendrik Potgieter. By insisting that the magistrate execute his duties from Schoonspruit, Potchefstroom was denied the status as the capital west of the Drakensberg. Secondly, it was hoped that the emigrant farmers living west of the Drakensberg would reconsider returning to Natal and so increase the number of emigrants in that area. The magistrate's court was eventually moved to Potchefstroom when the latter was recognised by the Natal Volksraad as a town and as the seat of the adjunct council. ${ }^{76}$

This situation resulted in a strained relationship between De Klerk and Potgieter, and probably contributed to De Klerk's resignation in August $1840 .{ }^{77}$ His request was at first denied ${ }^{78}$ and he continued in his duties until October $1841 .{ }^{79}$ Despite

70 See, eg, Volksraadsnotule Natal: 67, art 1 of the minutes of the Volksraad of 16 Nov 1840; and Volksraadsnotule Natal: 157-159, art 2 of the minutes of the Volksraad of 8-10 Aug 1842 - this latter decision refers to the farm "Doornkob aan Zand Revier Destrict Winburg" (Doornkop at Sand River District Winburg). See, also, Van der Walt sd: 20.

71 For more on the general history of Potchefstroom, see Van den Bergh 2013: 452-464; Van der Walt $s d$ : passim. See, too, on the early history of Winburg, Van der Walt $s d: 20-23$.

72 Also referred to in the documents of that time as "De Clercq" or "De Clerq".

73 Volksraadsnotule Natal: 16-17, art 3 of the minutes of the Volksraad of 7 Sep 1839. See, also, De Wet 1958: 244.

74 See the short description of the history of Klerksdorp available at http://www.klerksdorp.co.za/ history_klerksdorp (accessed 26 Feb 2016).

75 Van den Bergh 2013: 456-457.

76 Probably when the adjunct council was elected in Feb 1841. This was also the first time that the name Potchefstroom was explicitly mentioned in the minutes of the Natal Volksraad - see Volksraadsnotule Natal: 81-85, art 4 of the minutes of the Volksraad of 2 Feb 1841.

77 Volksraadsnotule Natal: 50-51, art 3 of the minutes of the Volksraad of 7 Aug 1840.

78 Most probably because there was no other suitable candidate at that time. The Volksraad responded that De Klerk himself had to nominate a successor - see supra $\mathrm{n} 77$. However, the reason for the denial was probably politically motivated as well: by insisting that De Klerk nominate his own successor, the Volksraad confirmed his authority and prevented the nomination of a representative from Potchefstroom.

79 As is evident from the minutes of the Volksraad. See Volksraadsnotule Natal: 62-65, art 8 of the minutes of the Volksraad of 28 Sep 1840; Volksraadsnotule Natal: 81-85, arts 3, 13, 14 and 19 of the minutes of the Volksraad of 2 Feb 1841; Volksraadsnotule Natal: 88, art 1 of the minutes of the Volksraad of 8 Apr 1841; and Volksraadsnotule Natal: 116-119, art 12 of the minutes of the Volksraad of 9 Oct 1841. 
the strained relationship with Potgieter, De Klerk appears to have been a popular magistrate as is evident from the petition signed by seventy-six persons requesting that he be re-appointed even before he officially resigned..$^{80}$ When De Klerk was at last released from his duties, he was apparently reluctant to relinquish his authority. $\mathrm{He}$ refused to hand over official documentation and continued to issue orders regarding the inspection of farms. The secretary of the Volksraad was instructed to resolve the matter. ${ }^{81}$

At the time of De Klerk's final resignation, P Louw was mentioned as his successor ${ }^{82}$ but no mention is made in the Natal Volksraad minutes of his official appointment or of his taking the oath as magistrate. In fact, this is the only time that Louw's name appears in the minutes of the Natal Volksraad for the period 1838 to 1845. However, two documents survived in which Louw signed in the capacity as deputy magistrate and the evidence therefore suggests that he undertook at least some of the duties of a magistrate by as early as November $1841 .{ }^{83}$

Not much is known about Louw's successors. Only one document mentions $\mathrm{JH}$ Grobler ${ }^{84}$ as the acting magistrate a year later ${ }^{85}$ One source ${ }^{86}$ suggests that Grobler was appointed as the first magistrate of Potchefstroom and supervised the development of that town in 1840. This date is however incorrect for two reasons: first, De Klerk remained the magistrate (albeit seated at Schoonspruit) until at least October 1841; and, secondly, Grobler supervised the development of Potchefstroom only in December $1841 .{ }^{87}$ It is unclear for which period he officiated or who his successor was. ${ }^{88}$

80 Volksraadsnotule Natal: 81-85, art 16 of the minutes of the Volksraad of 2 Feb 1841.

81 Volksraadsnotule Natal: 116-119, art 12 of the minutes of the Volksraad of 9 Oct 1841.

82 Ibid.

83 See National Archives Repository (Pretoria) [hereafter TAB] SS 1B R88/41 at 57-58 for a document dated 1 Nov 1841 and signed by, among others, the commandant (H Potgieter), the magistrate (PJ Louw - he signed as PJ Lou), five heemraden and three field-cornets. Also, in Oct 1850, a certain P Louw submitted a report to the Volksraad at Potchefstroom of his activities as "adjunk-Landdrost" (deputy magistrate) for Potchefstroom - see Volksraadsnotule Deel I: 145151, art 6 of the minutes of the Volksraad of 16 Oct 1850.

84 Grobler later actively participated in the official affairs of the ZAR. In 1852 he was one of the signatories of the Sand River Convention and in 1860 he was appointed as acting president in the absence of MW Pretorius. For more on his life, see Du Plessis 1977: 364-365.

85 TAB SS 1B R103/42 at 129, also published in Pretorius, Kruger \& Beyers 1937: 176, R103/42 dated 30 Nov 1842. This document, dated 30 Nov 1842, concerned a confirmation of the registration of the farm Vaalbank in favour of Daniel van Vuren (snr) and was signed by Grobler in his capacity as "fungeerend landdros" (acting magistrate).

86 Du Plessis 1977: 364.

87 See Van der Walt $s d: 12$.

88 However, as early as Aug $1845 \mathrm{JH}$ Visage was recognised as the acting magistrate of Potchefstroom - see, eg, Volksraadsnotule Deel I: 156-157, app 2/1845; Pretorius, Kruger \& Beyers 1937: 268269, R120j/47 dated 4 Mar 1847; and Volksraadsnotule Deel I: 68-69, art 2 of the minutes of the provisional sitting of the Volksraad at Ohrigstad of 14 May 1847. 


\section{Winburg}

The first magistrate for the district, $\mathrm{J}$ Vermeulen, was appointed in November $1840 .{ }^{89} \mathrm{He}$ was appointed in two capacities, namely that of provisional field-cornet and as acting magistrate. Although his appointment was never made permanent, he remained in office for more than two years. He resigned in October $1842^{90}$ and was succeeded by JJ Wessels in January $1843 .{ }^{91}$

The evidence suggests that the magistrate of Winburg was subject to the magistrate of Potchefstroom. In one document, Vermeulen referred to himself as the deputy magistrate..$^{92}$ In addition, upon their appointment in 1840 , the provisional magistrate and heemraden of Winburg were instructed to refer all serious matters that could not be settled by them to the "effective magistrate" of the court at the Sand River. ${ }^{93}$ Although the magisterial district of Winburg was also known as Sand River, it is not clear who the "effective magistrate" was or why there would be two magistrates at Winburg. There is no mention in the surviving documents of another magistrate at that time. It is therefore possible that the magistrate for Potchefstroom was seen as the "effective magistrate", being the only other Boer court west of the Drakensberg at that time. This argument would explain why Vermeulen was never appointed in a permanent capacity - because the provisional magistrate of Winburg was subject to the magistrate for Potchefstroom. Unfortunately, this, however, remains mere speculation due to the lack of evidence in this regard.

\section{The duties of the first magistrates}

During this period the various districts were sparsely populated and widespread. Farming duties and traveling distances resulted in isolated living conditions for many of the inhabitants. The Volksraad sat sporadically, and then mostly at Pietermaritzburg. ${ }^{94}$ The first magistrates served as a reminder of governmental

89 Volksraadsnotule Natal: 67, art 1 of the minutes of the Volksraad of 16 Nov 1840.

90 Volksraadsnotule Natal: 160-165, art 37 of the minutes of the Volksraad of 4-6 Oct 1842. He was requested to remain in his position for another three months.

91 Ibid. Magistrate Vermeulen personally nominated Wessels as his successor. No further mention is made of Wessels in his capacity as magistrate for Winburg in the minutes of the Natal Volksraad or of the Potchefstroom Volksraad after 1843 and it is uncertain for which period he served in this capacity.

92 This document no longer exists but is referred to in Volksraadsnotule Natal: 147-148, art 3 of the minutes of the Volksraad of 14 Mar 1842.

93 Volksraadsnotule Natal: 67, art 1 of the minutes of the Volksraad of 16 Nov 1840. The original wording of this provision reads: "Zaaken van Gewigt welke door hen tot geen schikking kan gebragt worden zullen ze moeten verwijzen na den Effectiefe landdrost aldaar, deeze hof bestaat aan de Santrevier" ("Serious matters that cannot be settled by them must be referred to the effective magistrate there, this court exists at the Sand River" - my translation).

94 As is evident when paging through the minutes of the Natal Volksraad. 
authority in their respective communities. ${ }^{95}$ They were therefore not only responsible for administering justice and ensuring the rule of law, but they also represented a twoway communication channel between the local inhabitants and the Volksraad. They were tasked with keeping their districts informed of important events and changes that could impact on the community as a whole,${ }^{96}$ and they provided the Volksraad with much needed feedback and input from the members of their districts. ${ }^{97}$ This becomes clear when studying the plethora of tasks that the magistrates were required to fulfil. Although it is difficult to provide a complete list of the duties and responsibilities assigned to the magistrates, some of these are set out below as is evident from the minutes of the Natal Volksraad.

\section{Duties regarding the administration of justice}

Some of the duties of the magistrates in terms of the 1838 and 1841 Regulations have already been described elsewhere. ${ }^{98}$ In general, the duties of the magistrates remained the same for both sets of regulations. Nevertheless, the abolition of the jury system for all but criminal trials involving the death penalty in terms of the 1841 Regulations meant that the magistrates' duties regarding the summoning of jury members were greatly reduced. Another change introduced by the 1841 Regulations was that tariffs of legal costs were now determined by the Volksraad, and no longer by the magistrates. ${ }^{99}$

95 See, eg, Volksraadsnotule Natal: 46-48, art 4 of the minutes of the Volksraad of 9 Jun 1840, which instructed the magistrate and two members of the heemraden of each district to represent the government, and in particular when they had to determine the town boundaries. On the important role of the magistrates in general, see Nieuwoudt 1964: 67-68.

96 Volksraadsnotule Natal: 14-15, art 5 of the minutes of the Volksraad of 5 Sep 1839 where the magistrate was instructed to remind the inhabitants that contamination of the drinking water and unnecessary shooting were prohibited; Volksraadsnotule Natal: 63-65, art 11 of the minutes of the Volksraad of 29 Sep 1840 in which the magistrate of Port Natal was instructed to convey to the English inhabitants there who wished to return to the Cape that they were permitted to travel only via the Drakensberg or by sea; and Volksraadsnotule Natal: 160-165, art 38 of the minutes of the Volksraad of 4-6 Oct 1842 in which all the magistrates were instructed to inform their local inhabitants of the due date for nominations for members of the Volksraad.

97 Volksraadsnotule Natal: 96-98, art 4 of the minutes of the Volksraad of 15 Jun 1841, detailing a response of the Volksraad to a written request from the magistrate of Port Natal on behalf of two local inhabitants asking for advice on the procedure regarding cross-border hunting trips; and Volksraadsnotule Natal: 142-144, art 8 of the minutes of the Volksraad of 24 Feb 1842, which sets out a request from the magistrate of Weenen on behalf of a group of native inhabitants asking for permission to conduct a revenge raid on the band of robbers from Joob's group ("Joob's volk") for a murder and livestock theft.

98 Wildenboer 2016: 174-182.

99 Prescribed tariffs for the territory west of the Drakensberg as suggested by magistrate De Klerk were approved by the Volksraad in Feb 1841 (in other words, in terms of the 1838 Regulations) - Volksraadsnotule Natal: 81-85, art 13 of the minutes of the Volksraad of 2 Feb 1841. The tariffs approved for the main district (Pietermaritzburg) also applied to the district of Weenen Volksraadsnotule Natal: 88-89, art 2 of the minutes of the Volksraad of 9 Apr 1841. I could not 
Other judicial duties of the magistrates included the execution of sentences; ${ }^{100}$ submission of three-monthly reports regarding their administration; ${ }^{101}$ notifying the heemraden of forthcoming court sittings; ${ }^{102}$ punishing offenders of the harbour regulations; ${ }^{103}$ providing a guarantee for the efficient administration of justice; ${ }^{104}$ keeping a record of all farms; ${ }^{105}$ drafting, witnessing and signing all deeds of transfer; ${ }^{106}$ issuing certificates of ownership; ${ }^{107}$ selling immovable property; ${ }^{108}$ appointing land inspectors, ${ }^{109}$ registering bonds over immoveable property; ${ }^{110}$

find any other tariffs for Pietermaritzburg approved during this period. The tariffs applicable in the district of Pietermaritzburg were sent to the magistrate for the territory west of the Drakensberg in Jan 1843 - see Volksraadsnotule Natal: 167-170, art 22 of the minutes of the Volksraad of 2-4 Jan 1843. For amendments to the existing tariffs, see Volksraadsnotule Natal: 173-177, art 4 of the minutes of the Volksraad of 3-6 Apr 1843.

100 See Volksraadsnotule Natal: 25-26, art 14 of the minutes of the Volksraad of 2 Jan 1840 where the magistrate was instructed to execute sentences of imprisonment and public labour; and Volksraadsnotule Natal: 46-48, art 2 of the minutes of the Volksraad of 9 Jun 1840 regarding the execution of a sentence for blasphemy. The magistrate of Pietermaritzburg was granted permission to appoint an "onder schout" to assist in supervising the prisoners - see Volksraadsnotule Natal: 323, app 9/1840 and Volksraadsnotule Natal: 32-34, art 7 of the minutes of the Volksraad of 5 Mar 1840 for the request of the magistrate and the response of the Volksraad respectively.

101 Volksraadsnotule Natal: 26-28, art 2 of the minutes of the Volksraad of 3 Jan 1840.

102 Volksraadsnotule Natal: 44-46, art 3 of the minutes of the Volksraad of 5 Jun 1840.

103 Volksraadsnotule Natal: 68-70, art 7 of the minutes of the Volksraad of 17 Nov 1840. For the instructions to the harbour master, see Volksraadsnotule Natal: 318-322, app 6/1840.

104 Volksraadsnotule Natal: 44-46, art 12 of the minutes of the Volksraad of 5 Jun 1840. A magistrate had to provide a document signed by four guarantors, each guaranteeing the amount of 10000 rijksdaalders should the magistrate not fulfil his duties; and the identities of these guarantors had to be approved by the Volksraad.

105 Volksraadsnotule Natal: 46-48, art 13 of the minutes of the Volksraad of 9 Jun 1840.

106 Volksraadsnotule Natal: 102-104, art 2 of the minutes of the Volksraad of 18 Jun 1841. The Secretary of the Volksraad stood in when the magistrate was unavailable or when the magistrate himself was the buyer or seller in a transaction - see Volksraadsnotule Natal: 119-121, art 13 of the minutes of the Volksraad of 11 Oct 1841.

107 Volksraadsnotule Natal: 157-159, art 4 of the minutes of the Volksraad of 8-10 Aug 1842. For an example of a certificate of ownership, see Pretorius, Kruger \& Beyers 1937: 176, R103/42 dated 30 Nov 1842. The Secretary and two other members of the Volksraad had to sign all deeds of grant (grondbriewe) - see Volksraadsnotule Natal: 113-115, arts 14 and 15 of the minutes of the Volksraad of 7 Oct 1841.

108 Volksraadsnotule Natal: 86-87, art 6 of the minutes of the Volksraad of 7 Apr 1841.

109 Volksraadsnotule Natal: 102-104, art 3 of the minutes of the Volksraad of 18 Jun 1841.

110 Volksraadsnotule Natal: 113-115, art 16 of the minutes of the Volksraad of 7 Oct 1841. Only the magistrate for Pietermaritzburg could register bonds. The administration fee per bond was six rijksdaalders, of which half went to the treasury. 
fulfilling notarial duties in the absence of a notary; ${ }^{111}$ solemnising marriages; $;{ }^{112}$ and the drafting and signing of contracts of employment. ${ }^{113}$

It is not clear how often magistrates were required to be at the office. In February 1842 the Volksraad stipulated that the person to be elected as magistrate for Weenen would be required to be available for official duties at least one day a week, but that he should be on standby for emergencies at any time. ${ }^{114}$ However, the magistrate could appoint a clerk ${ }^{115}$ to assist him, subject to the clerk then being available during office hours. Alternatively, if the magistrate preferred to handle all the administration personally, he could claim the clerk's salary in addition to his own remuneration, but was then compelled to report for duties every day. Nevertheless, this arrangement was most probably dictated by necessity and represented an exception to the rule; in general, magistrates were probably expected to be available during office hours, although this is a mere speculation. Lastly, magistrates were not eligible for election to the Volksraad. ${ }^{116}$

\section{Duties regarding the Orphan Chamber}

In June 1840 the magistrates of the outer districts (buiten districten) were appointed as agents of the Orphan Chamber (Weeskamer). ${ }^{117}$ They took over the duties of the existing Orphan Master (Weesheer), JB Rudolph, after allegations of mismanagement and irregularities concerning that office had surfaced. ${ }^{118}$ Rudolph was instructed

111 Volksraadsnotule Natal: 157-159, art 7 of the minutes of the Volksraad of 8-10 Aug 1842. In this instance the magistrate had to notarially execute an antenuptial contract as no notary was available.

112 Volksraadsnotule Natal: 38, art 7 of the register of the minutes of the Volksraad of 10 Mar 1840. This decision was confirmed by the Volksraad despite public protest - see Volksraadsnotule Natal: 81-85, art 17 of the minutes of the Volksraad of 2 Feb 1841.

113 Volksraadsnotule Natal: 28-30, art 11 of the minutes of the Volksraad of 6 Jan 1840. These contracts of employment concerned persons from the indigenous communities who wished to have their children employed, and applied to boys up to the age of twenty-five and girls up to the age of twenty-one.

114 Volksraadsnotule Natal: 142-144, art 13 of the minutes of the Volksraad of 24 Feb 1842. This arrangement also applied as an interim measure in the magisterial district of Port Natal after Maritz had submitted his resignation.

115 See, also, Volksraadsnotule Natal: 198-201, art 18 of the minutes of the Volksraad of 7 \& 8 Apr 1845 where the magistrate (presumably of Pietermaritzburg) later received permission to appoint a clerk for each sitting of court of the magistrate and heemraden at a prescribed daily fee.

116 Volksraadsnotule Natal: 121-123, art 9 of the minutes of the Volksraad of 12 Oct 1841. This restriction applied only for the duration of the appointment as magistrate.

117 Volksraadsnotule Natal: 46-48, art 11 of the minutes of the Volksraad of 9 Jun 1840.

118 There appears to have been dissatisfaction with Rudolph's administration, as three of his guarantors requested to be released from their obligations as early as Oct 1839 -Volksraadsnotule Natal: 18-20, art 8 of the minutes of the Volksraad of 4 Oct 1839. In response to the allegations, Rudolph claimed that a shortfall of 15000 rijksdaalders incurred by his office was due to the 
to decline any new estates for administration, ${ }^{119}$ and had to submit a report to the Volksraad on the finalisation of all existing estates. ${ }^{120}$

Henceforth, the magistrates were allowed to appoint executors to administer intestate estates as well as the estates of orphans subject to the same rules and regulations applicable in the Cape colony. ${ }^{121}$ As early as February 1841 the magistrate for the territory west of the Drakensberg was instructed to prepare accounts for all the estates of orphans, to settle all payments due to creditors, spouses and orphans above the age of majority and to keep all properties due to minor orphans under his supervision. He was permitted an executor's fee of five percent. ${ }^{122}$ Any estate moneys held by the Orphan Master could now be deposited with the magistrates, but in the event of enemy attacks, fire or other unforeseen circumstances these moneys could not be guaranteed. ${ }^{123}$ In addition, magistrates could appoint guardians to look after the financial interests of children where a parent entered into a second marriage. ${ }^{124}$

\section{Other duties}

Magistrates were also tasked with various non-judicial duties. Importantly, they handled the finances of their districts. They received all moneys for their districts on behalf of the government; ${ }^{125}$ settled approved governmental debts; $;{ }^{126}$ and accepted the deposit guarantee from the auction master. ${ }^{127}$ A statement of account had to be submitted to the Volksraad every three months. ${ }^{128}$

reluctance of the previous and current auction masters (IP Hammes and HJ Maartens respectively) to settle outstanding accounts. See Volksraadsnotule Natal: 92-94, art 1 of the minutes of the Volksraad of 12 Apr 1841; Volksraadsnotule Natal: 16-17, arts 9 \& 14 of the minutes of the Volksraad of 7 Sep 1839; Volksraadsnotule Natal: 22-23, art 1 of the minutes of the Volksraad of 11 Nov 1839; Volksraadsnotule Natal: 28-30, art 6 of the minutes of the Volksraad of 6 Jan 1840; and Volksraadsnotule Natal: 32-34, art 7 of the minutes of the Volksraad of 5 Mar 1840. It is therefore unclear whether Rudolph was personally to blame for the shortfall. The Secretary of the Volksraad was instructed to restore any cattle in the possession of the Orphan Master to the rightful minor owners and to institute legal proceedings against Rudolph if necessary: see Volksraadsnotule Natal: 121-123, art 14 of the minutes of the Volksraad of 12 Oct 1841.

119 Volksraadsnotule Natal: 92-94, art 1 of the minutes of the Volksraad of 12 Apr 1841.

120 Volksraadsnotule Natal: 81-85, art 26 of the minutes of the Volksraad of 2 Feb 1841.

121 Volksraadsnotule Natal: 100-102, art 16 of the minutes of the Volksraad of 17 Jun 1841.

122 Volksraadsnotule Natal: 81-85, art 13 of the minutes of the Volksraad of 2 Feb 1841.

123 Volksraadsnotule Natal: 100-102, art 16 of the minutes of the Volksraad of 17 Jun 1841.

124 Volksraadsnotule Natal: 94-95, art 2 of the minutes of the Volksraad of 13 Apr 1841; Volksraadsnotule Natal: 113-115, art 3 of the minutes of the Volksraad of 7 Oct 1841.

125 Volksraadsnotule Natal: 41-42, art 5 of the minutes of the Volksraad of 4 Apr 1840.

126 Volksraadsnotule Natal: 52-53, art 6 of the minutes of the Volksraad of 8 Aug 1840 esp n 50; Volksraadsnotule Natal: 157-159, art 14 of the minutes of the Volksraad of 8-10 Aug 1842. See, also, Volksraadsnotule Natal: 86-87, art 7 of the minutes of the Volksraad of 7 Apr 1841 where the magistrate of Pietermaritzburg was instructed to repay a government loan from EF Potgieter.

127 Volksraadsnotule Natal: 28-30, art 6 of the minutes of the Volksraad of 6 Jan 1840.

128 Volksraadsnotule Natal: 26-28, art 2 of the minutes of the Volksraad of 3 Jan 1840. For examples of quarterly financial reports of the magistrate of Pietermaritzburg, see Volksraadsnotule Natal: 
Citizens had to swear allegiance for a period of fifteen years to the newly found country in order to obtain citizenship. ${ }^{129}$ In terms of article 4 of the Burghership Law and the Possession of Fixed Property of 1841 (Natal) ${ }^{130}$ only a citizen could obtain immovable property. The administering of the oath was the responsibility of the magistrates. ${ }^{131}$ They also had to administer an oath to members of the heemraden, ${ }^{132}$ the harbour master ${ }^{133}$ and to members of special commissions. ${ }^{134}$ Foreigners who applied for citizenship had to obtain certificates of residence from either the local magistrate or from the local field-cornet and two respectable inhabitants of the area in which the applicant lived. To obtain a certificate, a person was required to have lived in the Republic for at least twelve consecutive months and to have conducted him- or herself "peaceably, submissive, honest, faithful, and sober". After obtaining such a certificate, the applicant had to pay the prescribed fee of 50 rijksdaalders and be confirmed by the Volksraad, and then take the oath of allegiance before the local magistrate. ${ }^{135}$

Magistrates were also responsible for issuing liquor licences. ${ }^{136}$ To qualify for such a licence, a person had to have a good reputation for not personally imbibing and had to obtain a certificate to this effect signed by two members of the Volksraad. ${ }^{137}$ The magistrate of Port Natal was further expected to act as harbour master in the latter's absence without additional remuneration, although he was permitted to delegate this responsibility. ${ }^{138}$ In one case the magistrate of Port Natal was responsible for monitoring diseases on incoming ships when he had to accompany the doctor on

344-345, app 20/1840 for the period Jan to Mar 1840; Volksraadsnotule Natal: 348-350, app 27/1840 for the period Apr to Sep 1840; and Volksraadsnotule Natal: 359-360, app 2/1841 for the period Oct to Dec 1840. The magistrate apologised for submitting the two quarterly reports for the months Apr to June and July to Sep in a consolidated report: see his letter to the Volksraad published in Volksraadsnotule Natal: 358-359, app 1/1841.

129 Volksraadsnotule Natal: 53-55, art 7 of the minutes of the Volksraad of 10 Aug 1840. See, also, Volksraadsnotule Natal: 14-15, art 8 of the minutes of the Volksraad of 5 Sep 1839.

130 Eybers 1918: 162-164, doc 103.

131 Volksraadsnotule Natal: 53-55, art 7 of the minutes of the Volksraad of 10 Aug 1840.

132 Volksraadsnotule Natal: 16-17, art 4 of the minutes of the Volksraad of 7 Sep 1839; Volksraadsnotule Natal: 50-51, art 10 of the minutes of the Volksraad of 7 Aug 1840.

133 Volksraadsnotule Natal: 68-70, art 5 of the minutes of the Volksraad of 17 Nov 1840.

134 Volksraadsnotule Natal: 104-105, art 11 of the minutes of the Volksraad of 19 Jun 1841. This oath was sworn before the magistrate of Pietermaritzburg. For the wording of the oath, see Volksraadsnotule Natal: 105 n 28.

135 Art 3 of the Burghership Law and the Possession of Fixed Property of 1841 (Natal) as translated by Eybers 1918: 162-164, doc 103. For a copy of the original Dutch version of the document, see Volksraadsnotule Natal: 372-374, app 12/1841. For the original and amended wording of this oath, see Volksraadsnotule Natal: 304-305, app 23/1839.

136 Volksraadsnotule Natal: 81-85, art 25 of the minutes of the Volksraad of 2 Feb 1841.

137 Ibid.

138 Volksraadsnotule Natal: 121-123, art 18 of the minutes of the Volksraad of 12 Oct 1841. 
board the Mazeppa to check for signs of smallpox. ${ }^{139}$ In an unrelated incident he was also tasked with investigating the disappearance of a boat for public use. ${ }^{140}$

Other duties included the issuing of permits for felling Tamboti trees in Port Natal ${ }^{141}$ recording of inboekelinge ${ }^{142}$ granting of permission for public assemblies for the purpose of signing a petition; ${ }^{143}$ investigating complaints regarding the distribution of livestock; ${ }^{144}$ building of a pound for stray livestock ${ }^{145}$ and drafting regulations pertaining to the pound; ${ }^{146}$ taking responsibility for recovered livestock that had previously been stolen; ${ }^{147}$ settling disputes regarding livestock; ${ }^{148}$ officially conveying decisions of the Volksraad to the field-cornets; ${ }^{149}$ surveying land; ${ }^{150}$ and reminding field-cornets of their duties. ${ }^{151}$

From time to time the magistrates were also tasked with duties pertaining to public works. In September 1840, magistrate Zietsman was instructed to build a prison at Pietermaritzburg. ${ }^{152}$ This was the second such instruction, the first one being issued to the magistrate and the heemraden of Pietermaritzburg earlier that year ${ }^{153}$ following a public petition in that regard. ${ }^{154}$ The Volksraad prescribed detailed building specifications for the proposed project. ${ }^{155}$ Furthermore, the magistrates were responsible for improving and maintaining the roads, although they could

139 Volksraadsnotule Natal: 46-48, art 10 of the minutes of the Volksraad of 9 Jun 1840.

140 Volksraadsnotule Natal: 63-65, art 21 of the minutes of the Volksraad of 29 Sep 1840.

141 Volksraadsnotule Natal: 12-14, art 6 of the minutes of the Volksraad of 29 Jun 1839.

142 Volksraadsnotule Natal: 28-30, art 10 of the minutes of the Volksraad of 6 Jan 1840. The magistrate had to issue a separate certificate for each child - Volksraadsnotule Natal: 86-87, art 3 of the minutes of the Volksraad of 7 Apr 1841. For more on the inboekelinge system, see Boeyens 1994: 187-214; and Morton 2005: 199-215.

143 Volksraadsnotule Natal: 40-41, art 7 of the minutes of the Volksraad of 3 Apr 1840.

144 Volksraadsnotule Natal: 35-36, art 1 of the minutes of the Volksraad of 6 Mar 1840.

145 Volksraadsnotule Natal: 53-55, art 6 of the minutes of the Volksraad of 10 Aug 1840.

146 Volksraadsnotule Natal: 38-39, art 4 of the minutes of the Volksraad of 1 Apr 1840.

147 Volksraadsnotule Natal: 28-30, art 12 of the minutes of the Volksraad of 6 Jan 1840.

148 Volksraadsnotule Natal: 113-115, art 2 of the minutes of the Volksraad of 7 Oct 1841.

149 Volksraadsnotule Natal: 63-65, art 12 of the minutes of the Volksraad of 29 Sep 1840; Volksraadsnotule Natal: 86-87, art 2 of the minutes of the Volksraad of 7 Apr 1841.

150 Volksraadsnotule Natal: 20-21, art 5 of the minutes of the Volksraad of 8 Nov 1839.

151 Volksraadsnotule Natal: 104-105, art 4 of the minutes of the Volksraad of 19 Jun 1841.

152 Volksraadsnotule Natal: 62-63, art 10 of the minutes of the Volksraad of 28 Sep 1840.

153 Volksraadsnotule Natal: 28-30, art 2 of the minutes of the Volksraad of 6 Jan 1840.

154 Volksraadsnotule Natal: 314-315, app 31/1839.

155 Volksraadsnotule Natal: 20-21, art 3 of the minutes of the Volksraad of 7 Nov 1839. These specifications required the following: twenty-five feet by eighteen feet with a flat roof and the lowest wall at nine feet built of planed yellow wood. The building had to contain a wall in the middle and each room had to have at least one window, a door and a doorframe. The second instructions amended the size of the building to twenty-five feet by twenty-four feet, but did not say anything regarding the further specifications: see Volksraadsnotule Natal: 28-30, art 2 of the minutes of the Volksraad of 6 Jan 1840. For more on the prison system in Natal after 1845, see Peté 2015: 102-118. 
delegate this responsibility. ${ }^{156}$ Other related duties included the building of a powder magazine; ${ }^{157}$ preparing an estimate of the costs and a report on the viability of proposed waterworks; ${ }^{158}$ renting a house for the purpose of Volksraad assemblies; ${ }^{159}$ building a council house from funds to be sourced; ${ }^{160}$ and acquiring shovels and pick-axes for governmental use. ${ }^{161}$

\section{Summary}

From the above it becomes clear that the magistrate played a crucial role in the general administration beyond the Orange River during the period 1839 to 1843 . His duties extended way beyond the usual judicial responsibilities. He was seen as an intermediary between the government - in most cases, seated far away - and the inhabitants of his district. It is for this reason that various magisterial districts were established on both sides of the Drakensberg. As the representative of the government, a magistrate not only had to dispense justice, but also had to manage the finances of his district, convey information and announcements to the inhabitants and supervise building projects relating to public works. However, he also conveyed the needs and concerns of the inhabitants to the government, and in this sense acted as the representative of the people.

\section{BIBLIOGRAPHY}

Anonymous (1977) "Badenhorst, Lourens" in Suid-Afrikaanse Biografiese Woordeboek vol 3 (Cape Town): 40-41

Bird, John (1888) The Annals of Natal 1495 to 1845 vol 1 (Pietermaritzburg)

Boeyens, JCA (1994) “'Black ivory': The indenture system and slavery in Zoutpansberg, 18481869" in EA Eldredge \& F Morton (eds) Slavery in South Africa: Captive Labor on the Dutch Frontier (Pietermaritzburg): 187-214

Breytenbach, JH (ed) (sd) Notule van die Natalse Volksraad (Volledig met Alle Bylae Daarby) (1838-1845) (Cape Town) [short reference Volksraadsnotule Natal]

156 Volksraadsnotule Natal: 91-92, art 1 of the minutes of the Volksraad of 11 Apr 1841.

157 Volksraadsnotule Natal: 28-30, art 3 of the minutes of the Volksraad of 6 Jan 1840. This instruction was issued to the magistrate and heemraden and the building had to be at least twelve feet by fifteen feet.

158 Volksraadsnotule Natal: 96-98, art 3 of the minutes of the Volksraad of 15 Jun 1841; Volksraadsnotule Natal: 135-136, art 2 of the minutes of the Volksraad of 10 Jan 1842. In terms of the latter instruction the magistrate of Port Natal had to invite tenders on the building of a dam and inform the Volksraad of the outcome of the process; the magistrate also had to submit a very comprehensive report to the Volksraad on the geographical and geological viability of such a dam.

159 Volksraadsnotule Natal: 121-123, art 15 of the minutes of the Volksraad of 12 Oct 1841.

$160 \mathrm{Ibid}$. This instruction was issued to the magistrate and heemraden.

161 Volksraadsnotule Natal: 152-155, art 4 of the minutes of the Volksraad of 29 Apr 1842. 
Breytenbach, JH \& Pretorius, HS (eds) (sd) Notule van die Volksraad van die Suid-Afrikaanse Republiek (Volledig met Alle Bylae Daarby) Deel I (1844-1850) in South African Archival Records Transvaal No 1 (Cape Town) [short reference Volksraadsnotule Deel I]

Cubbin, AE (1992) "An exposition of the clash of Anglo-Voortrekker interests at Port Natal leading to the military conflict of 23-24 May 1842" Historia 37(2): 48-69

Davenport, TRH \& Saunders, Christopher (2000) South Africa A Modern History (Houndmills)

De Wet, JC (1958) “Die Romeins-Hollandse reg in Suid-Afrika na 1806” THRHR 21: 239-248

Du Plessis, JS (1977) “Grobler, Johannes Hermanus” in Suid-Afrikaanse Biografiese Woordeboek vol 3 (Cape Town): 364-365

Eybers, GW (1918) Select Constitutional Documents Illustrating South African History 17951910 (London)

Koopman, Adrian (2004) "The names and the naming of Durban" Natalia 34: 70-87

Morton, Fred (2005) "Female Inboekelinge in the South African Republic, 1850-1880" Slavery and Abolition 26(2): 199-215

Nathan, Manfred (1937) The Voortrekkers of South Africa From the Earliest Times to the Foundation of the Republics (London)

Nieuwoudt, CF (1964) Die Ontstaan en Ontwikkeling van die Uitvoerende Gesag in die ZuidAfrikaansche Republiek (Cape Town)

Peté, Stephen Allister (2015) "Like a bad penny: The problem of chronic overcrowding in the prisons of colonial Natal: 1845 to 1910 (Part 1)" Fundamina. A J of Legal History 21(1): $102-118$

Preller, Gustav S (1920) Voortrekkermense: 'n Vijftal Oorspronklike Dokumente oor die Geskiedenis van die Voortrek (Cape Town)

Preller, Gustav S (1938) Voortrekkermense V (Cape Town)

Preller, Gustav S (1988) Joernaal van ' $n$ Trek. Uit die Dagboek van Erasmus Smit. Reissued with a new introduction by M Scholtz (Cape Town)

Pretorius, HS, Kruger, DW \& Beyers, C (eds) (1937) Voortrekker-Argiefstukke 1829-1849 (Pretoria)

Stockenström, Eric (1925) Lotgevalle van die Voortrekkers in Natal na Bloedrivier 1838-1843 (Bloemfontein)

Tabler, Edward C (1977) Pioneers of Natal and Southeastern Africa 1552-1878 (Cape Town)

Theal, George McCall (1908) History of South Africa since September 1795 vol 2 (London)

Theal, George McCall (1915) History of South Africa from 1795 to 1872 vol 2 (London)

Van den Bergh, Gert (2013) "Die aandeel van Potchefstroom in Voortrekkerstaasvestiging [sic]" Tydskrif vir Geesteswetenskappe 53(3): 452-464

Van der Walt, AJH et al (sd) Potchefstroom 1838-1938 (Johannesburg)

Wildenboer, Liezl (2016) "Judicial administration beyond the Orange River from 1838 to 1843" Fundamina. A J of Legal History 22(2): 173-190 